\title{
Tax avoidance as a driver of mergers and acquisitions*
}

\author{
Thomas Belz, Mannheim University \\ Leslie Robinson, Tuck School of Business at Dartmouth \\ Martin Ruf, Tübingen University \\ Christian Steffens, Mannheim University
}

December 2013

\begin{abstract}
Following a merger or acquisition, a target firm's effective tax rate decreases on average by 3 percentage points. This decline is as high as 8 percentage points when the acquiring firm is tax aggressive. Further, target firm profitability decreases, particularly in the case of targets having a higher statutory tax rate than the acquirer. These results point to acquiring firms' ability to more effectively lower target firms' tax burdens after the deal takes place being a potential driver of the deal. On the contrary we do not find a change in target leverage post deal. The latter finding we attribute to the existence of group taxation regimes in many countries, which makes it more efficient to use a highly levered holding company to acquire the target instead of altering the leverage of the target itself.
\end{abstract}

Keywords: Tax accounting, mergers and acquisitions, tax management, propensity score matching

JEL Classification: M41; G34; H25

* The authors appreciate constructive comments from Martin Jacob, Johannes Voget, Ulrich Schreiber and workshop participants at Mannheim University, Tuck School of Business at Dartmouth, the 2012 European Accounting Association Annual Congress, the 2012 EIASM workshop on current research in taxation in Münster, the 2012 American Accounting Association Annual Meeting and the 2013 IIPF Annual Conference. Martin Ruf would also like to thank the Oxford University Center for Business Taxation and the Tuck School of Business at Dartmouth for the kind hospitality while working on this project and the German Science Foundation (DFG) for its support. 


\section{Introduction}

Mergers and acquisitions are an increasingly important form of business investment. The value of cross-border deals rose by 53 percent in 2011 to $\$ 526$ billion, compared to crossborder Greenfield investment projects valued at $\$ 904$ billion during that same year (UNCTAD 2012). Thus, understanding the drivers of mergers and acquisitions is a key part of understanding the drivers of business investment in general.

Mergers and acquisitions take place primarily because of 'ownership advantages'. Ownership advantages arise when a change in ownership of the target firm is expected to provide a source of value creation, either by increasing the target's expected future cash flows or decreasing risk. For instance, the acquirer may believe that it is able to manage the target better than the seller. Such ownership advantages are expected to improve future cash flows, enabling the acquirer to outbid the reservation price of the initial owner and increase the likelihood that the deal takes place.

There are many possible sources of ownership advantages. While there is an extensive literature on the change in operating performance following mergers and acquisitions (see Martynova and Renneboog (2008) for a survey), the potential importance of tax management has been ignored. Lowering the target firm's tax burden is one important way that an acquiring firm can generate ownership advantages. The average firm-level effective tax rate in our sample is around 34 percent, suggesting governments lay claim to one third of pre-tax profits. If the acquirer believes it is able to minimize the target's taxes more efficiently than the initial owner, it will expect to generate a higher after-tax cash flow.

We investigate changes in the tax avoidance of targets in a sample of European mergers and acquisitions taking place between 1996 and 2009, using propensity score matching to 
estimate the average treatment effect. As a unique feature of our analysis we observe operating and financial data of the 'stand-alone' target firm before and after the deal by using unconsolidated accounting data. Specifically, we compare three indicators of tax avoidance at the target - effective tax rate, profitability, and leverage - before and after the deal. Our results generally show that target tax avoidance improves, resulting in lower tax payments post deal. Thus, more efficient tax management by acquirers could be a driver of mergers and acquisitions.

We first examine the potential role of acquirers in target tax avoidance following both national (acquirer and target are resident in the same country) and international (acquirer and target are resident in a different country) deals. The indicator of tax avoidance that we examine is the target firm's (accounting) effective tax rate (ETR), or tax expense divided by pre-tax income. This measure reflects tax management that generates permanent book-tax differences in the target firm. ${ }^{1}$ We find an average decrease in a target's ETR post-deal of 3 percentage points. Moreover, this decrease is especially pronounced - around 8 percentage points - following deals by tax aggressive acquirers having themselves a relatively low ETR. Thus, acquirers appear to play a significant role in determining the level of tax avoidance that a target undertakes once it becomes part of the group.

We also examine the potential role of acquirers in target tax avoidance that is only possible following international deals. While reductions in a target firm's ETR imply more efficient tax management at the target firm by the acquirer, ownership advantages also arise if the target firm enjoys new opportunities to reduce its tax burden by being part of a

\footnotetext{
${ }^{1}$ Permanent differences arise when a transaction affects taxable income but not book income, or vice versa. A favorable tax planning strategy would be one that lowers taxable income without lowering book income.
} 
multinational group. We examine two prominent international tax planning strategies transfer pricing and debt shifting. Here, we do not focus on the target firm's ETR because these strategies would not impact such a measure. ${ }^{2}$

To examine the use of transfer pricing, we investigate changes in target profitability. Consistent with Ravenscraft and Scherer (1989) and Clark and Ofek (1994) we find a decrease in target profitability post deal in general. Splitting the sample between high tax and low tax targets (targets facing a higher or lower statutory tax rate than the acquirer, respectively), we find a decrease in profitability only in high tax targets. This result points to international tax planning (i.e., transfer pricing) by the acquirer contributing to the observed decrease in target profitability following mergers and acquisitions.

To examine the use of debt shifting, we investigate changes in target leverage. While we do not find a significant change in target leverage post deal, we find empirical evidence consistent with use of 'debt push-down' strategies being the possible reason for this finding. In countries offering group taxation, a promising tax strategy related to mergers and acquisitions is to load a holding company with debt in order to acquire the target. As a result, the leverage of the holding company increases, while the leverage of the target remains unchanged. Group taxation then allows for consolidation when computing taxable income such that the interest expense of the holding company offsets the earnings of the target (see Section 4.3.1 for further discussion). ${ }^{3}$

\footnotetext{
${ }^{2}$ If a multinational firm uses transfer prices or debt shifting to re-allocate target profits to other members of the group, this affects both the target's book and taxable income. While these strategies may impact the consolidated ETR of the multinational firm, they will not impact the individual target firm's ETR.

${ }^{3}$ See "Kastljós: Álverin koma sér hjá skattgreiðslum" by Helgi Seljan, Icelandic National Television Commentary, March 2013, for a discussion of this strategy in Iceland by large U.S. multinational firms.
} 
Our study is related to three distinct strands of literature. First, there is a growing literature that considers the role of tax avoidance in mergers and acquisitions. ${ }^{4}$ Kaplan (1989) and Devos, Kadapakkam, and Krishnamurthy (2009) estimate the extent to which tax savings are responsible for merger gains. Blouin, Collins, and Shackelford (2005) examine changes in taxable income of U.S.-domiciled firms after being acquired by foreign firms. Martin, Wang, and Zou (2012) examine the link between target tax aggressiveness and acquisition premiums. Chow, Klassen, and Liu (2013) and Col (2012) examine announcement returns of targets and acquirers to determine whether anticipated (future) tax avoidance is an underlying source of merger gains. These last two studies are most closely related to ours, though neither study examines the precise channel through which tax avoidance occurs post-deal. Our study documents increased tax avoidance of targets post deal with respect to the target's ETR and international profit shifting.

Second, there is extensive literature evaluating the operating performance following mergers and acquisitions as reviewed in Martynova and Renneboog (2008). The empirical evidence is mixed -14 out of 26 studies report a post-merger decline in the operating returns of merged firms, 7 papers show insignificant changes in profitability and only 5 papers provide evidence of a significantly positive increase. Only two studies - Ravenscraft and Scherer (1989) and Clark and Ofek (1994) - focus on the post-merger operating performance of the target as we do. We find a decrease in target operating performance following takeovers (consistent with their results) and provide tax motivated transfer pricing as a partial explanation for this finding.

\footnotetext{
4 There is also a literature that considers taxes as a source of value creation in mergers and acquisitions, however, it focuses on taxes at the transaction-level (e.g., Auerbach and Reishus, 1987; Erickson, 1998).
} 
Third, there is a large literature on tax planning, e.g. Chen, Chen, Chen, and Shevlin (2010) with respect to ETRs, Desai, Foley, and Hines. (2004) with respect to international debt shifting and Huizinga and Laeven (2008) for international transfer pricing. We contribute to this literature by using mergers and acquisitions as a new setting in which to identify tax motivated international profit and debt shifting.

Our study points to the economic importance of tax avoidance as a driver of mergers and acquisitions. Aside from improving a firm's after-tax profit, effective tax management may be important for a firm looking to prevent a hostile takeover. Potential acquirers with more efficient tax management may be able to competitively bid for target firms. Our results also give rise to tax policy concerns. If some types of tax avoidance are only available to multinational groups (e.g., transfer pricing), then international acquirers may enjoy an exclusive ownership advantage with respect to national targets. As a result tax systems could force national firms in international takeovers.

Section 2 develops testable hypotheses. Section 3 describes the empirical methodology and the data. Section 4 presents empirical results. Section 5 concludes.

\section{Tax avoidance as a driver of mergers and acquisitions}

The initial owner of a firm will sell the firm if the offer price exceeds his reservation price (see Hansen 1987). The initial owner's reservation price is equal to the capitalized earnings

value $\frac{x}{r}$ of the expected cash $x$ from keeping the firm, where $r$ is the discount rate. The expected cash $x^{*}$ of a potential acquirer may differ due to non-tax reasons (e.g. synergies, see Weston et al. 2004, p. 130, for potential non-tax reasons for such differences) or due to tax 
reasons. Regardless of the reasons, if a potential acquirer expects to generate a greater cash flow from owning the firm than the initial owner $\left(x^{*}>x\right)$ he has an ownership advantage (see Becker and Fuest, 2010; Desai and Hines, 2003). The resulting capitalized earnings value of the acquirer is $\frac{x^{*}}{r}$, the maximum offer price the acquirer is willing to bid. If a potential acquirer has an ownership advantage the offer price of the acquirer exceeds the reservation price of the initial owner, implying that the deal will take place when $\frac{x^{*}}{r}>\frac{x}{r}$.

There are several economically significant tax reasons that a potential acquirer would expect higher cash flows than those generated by the initial owner. First, both national and international deals may provide an acquirer with the ability to lower a target's ETR through more effective tax management at the level of the target itself. Second, in the case of international deals, an acquirer may be able to re-allocate the income of a target facing a relatively high tax rate to another member of the multinational group where the income is taxed at a lower rate. This is typically accomplished through transfer pricing or debt shifting. We next describe each measure of tax avoidance in turn.

2.1. Effective Tax Rate (ETR). Accounting ETRs are widely employed to measure the tax avoidance of firms (see summary provided in Hanlon and Heitzman, 2010 and as examples the studies of Chen et al., 2010; Dyreng, Hanlon, and Maydew, 2010; Phillips, 2003; Rego, 2003; Mills, Erickson, and Maydew, 1998). ${ }^{5}$ An accounting ETR is impacted by tax planning strategies that generate permanent book-tax differences. Examples (see Chen et al. 2010) of such tax planning are investments in tax-exempt or tax-favored assets, participation in tax shelters that give rise to losses for tax purposes but not for book purposes,

\footnotetext{
${ }^{5}$ Our ETR measure comes from Amadeus (see Section 3.1 for a discussion of our data source) and is defined as tax expense (TAXA) divided by pre-tax book income (PLBT).
} 
the use of tax credits or the use of favorable depreciation schemes available for tax purposes only. Scholes et al. (2009), pp. 39-40, provide a comprehensive overview of possible booktax differences. Moreover, we rely on a three-period average measure to mitigate the effects of transitory changes in annual ETRs. ${ }^{6}$ Such tax avoidance is possible for national as well as multinational firms. If a target's tax avoidance improves after an acquisition, we expect to observe a drop in the target's ETR.

If the target's effective tax rate ETR* post-deal is lower than the target's ETR preacquisition, and a potentail acquirer and initial owner are equally capable of generating the same pre-tax book income (denoted BI) at the level of the target, then the expected after-tax cash flow for a potential acquirer is $x^{*}=\left(1-E T R^{*}\right) B I$ and for the initial owner is $x=$ $(1-E T R) B I$. Due to the lower ETR $\left(E T R^{*}<E T R\right)$ the deal will take place because $\frac{x^{*}}{r}=\frac{(1-E T R) B I}{r}>\frac{x}{r}=\frac{(1-E T R) B I}{r}$. Empirically, if we find a lower target ETR post deal, then improved target tax avoidance by the acquirer could be a driver of the deal.

Moreover, acquiring firms differ in their tax aggressiveness. Since acquirers will benefit from their tax planning experience when restructuring the target's affairs in a tax efficient manner ${ }^{7}$, we expect to observe a larger decrease in a target's ETR following acquisitions by tax aggressive acquirers. We thus differentiate acquirers with respect to their ETR preacquisition. We consider acquirers having an ETR below the country specific sample average as especially tax aggressive.

\footnotetext{
${ }^{6}$ Dyreng, Hanlon, Maydew (2008) and Klassen and LapLante (2012) recognize that multi-year measures of ETRs are an improvement over single year measures. We settle on a three-year measure in our study to avoid a significant reduction in our sample size though, in some analyses, those authors consider longer periods.

${ }^{7}$ The argument in Dyreng, Hanlon, and Maydew (2010), that top executives have effects on their firms' tax avoidance, is similar. Also see Chow, Klassen, and Liu (2013), Col (2012).
} 
2.2. Transfer pricing. The ability to set transfer prices on intra-firm trade provides multinational firms with flexibility as to how to allocate income across national jurisdictions imposing different tax rates (see Huizinga and Laeven, 2008). The possibilities to shift profits potentially increase substantially following an international deal. ${ }^{8}$ For instance, firms can alter prices charged on intragroup services or deliveries, or even create new intragroup services or deliveries. There is no data available on intragroup services and deliveries, or their pricing. So, we follow the literature on tax-motivated transfer pricing and relate a firm's profitability to its tax incentives to shift income via transfer pricing.

Profit shifting generates tax savings when income is shifted from high-tax locations to low-tax locations. International deals offer the possibility to shift profits out of the target's taxing jurisdiction for the first time. The resulting tax savings of the acquirer may constitute the ownership advantage necessary to acquire the target. The target's book income is reduced by profits shifted away $(P S)$, while the book income of another multinational group member offering a lower tax rate $\tau^{p s}$ is increased. If the resulting new capitalized earnings value of the firm is higher than the reservation price, the deal takes $\operatorname{place}\left(\frac{x^{*}}{r}=\frac{(1-\tau)(B I-P S)+\left(1-\tau^{p S}\right) P S}{r}>\frac{x}{r}\right)$.

First, we compare the effect of national versus international takeovers on a target's profitability. In order to separate changes in target profitability arising from transfer pricing (as opposed to debt shifting), we focus on profitability defined as earnings before interest and taxes (EBIT) over total assets (see Huizinga and Laeven, 2008). If the opportunity to shift

\footnotetext{
${ }^{8}$ We recognize there may be opportunities to shift profits after a national deal in order to take advantage of various sub national rates. However, profit shifting is a significant source of tax savings in multinational firms, and hence, more likely to motivate an international deal.
} 
profits out of the target motivated the deal, we expect to observe a decrease in the target's profitability. This decrease should be especially pronounced following international deals.

Next, we differentiate with respect to the statutory tax rate of the acquirer versus the target. If the acquirer faces a lower statutory tax rate than the target, we expect a decrease in target profitability (if instead the target's tax rate is lower, the acquirer may locate additional profits which would increase target profitability). We also examine whether target profitability decreases when any member of the acquirer's multinational group (and hence new group of the target) faces a lower statutory rate than the target.

2.3. Debt shifting. Firm owners may choose to finance their operations with either debt or equity. For tax purposes dividends paid on equity in general do not lower taxable income, while interest paid on debt is tax deductible. From the tax perspective of the debtor, greater interest payments would be expected to reduce its tax burden. Thus, the use of debt finance at the level of the target as a debtor is tax advantageous (see Huizinga, Laeven, and Nicodeme, 2008).

On the contrary this conclusion may reverse at the level of the creditor. Taxes due on dividend earnings at the level of the firm owner are frequently lower than taxes due on interest earnings. Overall the use of debt finance is thus only a worthwhile policy, if the tax rate on the resulting interest earnings is sufficiently low or even zero.

Internally ${ }^{9}$ debt financing a target will not result in a lower ETR but instead in a reduction of book income and an increase in interest income $I I$ available to the firm owner. If the tax rate on interest income $\tau^{i}$ at the level of the creditor is lower than the firm's statutory tax

\footnotetext{
${ }^{9}$ It is easier to illustrate the argument relying on internal debt finance. However, using external debt financing gives similar results: Replacing equity with external debt finance in the target allows the acquirer to use the released equity in a tax-favored location instead. This results in similar tax savings.
} 
rate $^{10} \tau$, the tax load on the firm's earnings decreases and the resulting new capitalized earnings value of the target is $\frac{(1-\tau)(B I-I I)+\left(1-\tau^{i}\right) I I}{r}$. If the new capitalized earnings value of the firm exceeds the reservation price of the initial owner $\left(\frac{x^{*}}{r}=\frac{(1-\tau)(B I-I I)+\left(1-\tau^{i}\right) I I}{r}>\frac{x}{r}\right)$, the deal will take place.

In a domestic setting the available tax rate on interest income typically is not lower than the corporate tax rate. On the contrary multinational groups benefit from the set of available corporate tax rates worldwide in establishing group members in low tax countries (see Huizinga et al. 2008), including many zero taxed tax havens (see Hines and Rice 1994). Figure 1 illustrates the argument.

- Insert Figure 1 about here -

If a firm uses debt instead of equity to finance its operations, the resulting interest expenses will affect book as well as taxable income. Thus nominator and denominator of the ETR are likewise affected. The ETR will not or at least incompletely reflect the use of debt finance. Instead we investigate this issue considering the change in a target's leverage (total debt over total assets) following an acquisition.

If a target's tax avoidance improves after an acquisition, we expect to observe an increase in the target's leverage. This increase should be more pronounced following international mergers and acquisitions. Then a purely national target without the opportunity to debt shift income to group members in low tax countries becomes part of a multinational group due to

\footnotetext{
${ }^{10}$ To simplify the argument we assume that book income is equal to taxable income. We can thus use the firm's statutory tax rate (which is relevant for debt and profit shifting incentives) in the formulas instead of the ETR.
} 
the acquisition. Within the group of international mergers \& acquisitions we expect to observe an especially pronounced increase in the target leverage, if the acquirer or any group member of the acquirer's multinational group has a lower tax rate than the target.

The latter two channels for tax avoidance following an international deal may give rise to tax policy concerns. Since in most cases purely national firms or groups can neither use debt shifting nor transfer pricing to significantly lower their tax burden (or the costs of doing so are prohibitively high), international acquirers have a systematic tax driven ownership advantage allowing them to acquire such targets. This may contribute to the empirical finding of multinational networks trading at a premium relative to a benchmark portfolio of purely national firms (see Creal, Rogers, Robinson, and Zechman, 2013).

\section{Empirical Analysis}

3.1. Data. We extract all mergers and acquisitions taking place between 1996 and 2009 from the Bureau van Dijk Zephyr database that result in a 100 percent ownership change in the target firm. We then merge the resulting targets with the Bureau van Dijk Amadeus database containing unconsolidated financial data for European firms, allowing us to evaluate changes in the target's ETR, profitability and leverage both before and after the deal. We then delete targets with unlimited liability, since such firms are typically organized as partnerships, leaving as our focus target corporations only. Pursuant to an acquisition a partnership's assets may be stepped up resulting in higher depreciation and lower tax payments, possibly distorting our results (see Erickson and Wang, 2000).

After these steps we are left with 1,440 targets for which we observe financial statements three years before and one year after the deal. To these we add all firms available in 
Amadeus between 1996 and 2009 offering at least five consecutive financial statements as potential matches. We then delete all firms showing losses, since the tax planning incentives of loss firms are less clear-cut (see De Simone and Seidman, 2013). Out of the remaining 1,078 targets only 832 offer information on all regressors of the selection equation, thus 832 targets and 1.97 million potential matches enter the selection equation. Table 1 provides descriptive statistics for all variables used in the selection equation. Out of the 832 targets entering the selection equation, only 529 offer information on the outcome variables - the 3year averages ${ }^{11}$ of ETR, profitability and leverage after the deal.

- Insert Table 1 about here -

Since in some cases, we anticipate especially pronounced changes in tax avoidance after international deals, we group the mergers and acquisitions in our sample into national and international. If the acquirer or any group member ${ }^{12}$ of the acquirer is from a country different from the target's country of residency, we classify the deal as international. If the acquirer is resident in the same country as the target, we classify the deal as national.

Figure 2 gives an overview of the regional origin of acquirers in our sample. By far the most acquirers come from the U.K. Interestingly, U.S. acquirers are important, even though

\footnotetext{
${ }^{11}$ Thus, we consider only outcomes of targets for which we observe financial statements three years before and three years after the deal.

${ }^{12} \mathrm{We}$ use the Amadeus owner database to identify group members of the acquirer. Firms are identified as group members, if the group parent has a total ownership in the firm exceeding 90 percent. Unfortunately the Amadeus owner database is incomplete and we are not able to observe all group members of the acquirer. We thus may classify deals erroneously as national in some cases. We are not able to check whether the target belonged to a multinational group pre deal, since the Amadeus owner database does not provide historical ownership data. Group members of the target identified using the Amadeus owner database are members of the new group established following the acquisition of the target.
} 
we consider a sample of European targets only. This is consistent with other studies on international mergers and acquisitions, where typically the U.S. and the U.K. are the countries with the most acquirers (see e.g. Huizinga and Voget, 2009).

- Insert figure 2 about here -

3.2. Econometric Approach. If we observe a change in any of our variables of interest (ETR, leverage or profitability) after a deal, we would like to attribute those changes to changes in target tax avoidance carried out by the acquirer. To rule out the possibility that the change would have otherwise occurred requires a counterfactual framework. That is, we observe the change in our variables of interest after the deal and we would like to compare this to the change, if the deal had not taken place. Since it is not possible to observe this counterfactual outcome, we employ propensity score matching to construct a counterfactual control group.

The idea of propensity score matching is to identify firms being ideally identical to the target firms besides for the fact of not being sold. This is an econometric effort to replicate as close as possible the laboratory conditions available in natural sciences: There is a population of identical examination units out of which one part receives a treatment and the others not. The observed difference in the outcome variables of interest is then due to the treatment. The treatment in question here is the sale of the target firm.

Matching based on the propensity score works in two steps (see e.g. Wooldridge, 2002, Chapter 18). First, we run a probit regression evaluating the probability to become a target 
conditional on a vector of observed covariates (selection equation). Based on the regression results we predict the probability to become a target for each firm in our sample.

Second, there are four matching methods (nearest neighbor matching, radius matching, caliper matching and kernel matching) available in order to match each treated firm with one or several control firms using the results of the selection equation. The idea is to match each target with a non-sold firm having the same probability of becoming a target based on the results of the selection equation.

Nearest neighbor matching matches to each treated firm the control firm with the closest propensity score. Caliper matching is a variation of nearest neighbor matching. It matches treatment firms with control firms only if the propensity score of both firms is within a predefined radius. By imposing a maximum tolerance level of the distance between treated and control firms, caliper matching attempts to improve the overall matching quality. Instead of matching one of the treated firms with its closest control firm within a radius, radius matching selects all the firms that fall within the predefined caliper. Kernel matching uses all available controls as matches, but uses weights inversely proportional to the distance between the propensity scores of treated firms and available controls. In order to make use of our large set of potential matches, we focus primarily on radius and kernel matching.

For a given propensity score, exposure to treatment is supposed to be random and therefore treated and control units should be on average observationally identical. We check this balancing property and compare the difference in the regressors of the selection equation between the sold (treatment group) and the non-sold (control group) firms. If the balancing property holds, the difference in these regressors should be considerably smaller after 
matching than before. Since we control for all variables typically employed for predicting targets in the literature, we expect to fulfill this condition.

Formally (see Wooldridge 2002, pp. 604-621), we are interested in measuring the average treatment effect of the treated $A T T_{1}=E\left(y_{1}-y_{0} \mid w=1\right) \cdot y_{1}$ denotes the outcome (in our case the change in the ETR, the leverage or the profitability) with treatment and $y_{0}$ the outcome without treatment. $w$ is a binary variable indicating participation $(w=1)$ in treatment (in our case being acquired) or not $(w=0)$.

A simple approach to estimate $A T T_{1}$ would be to compare the mean of the outcome variable between sold and non-sold firms. However, such an approach is only possible if there is no self-selection into treatment: $E\left(y_{1} \mid w=1\right)=E\left(y_{1}\right)$ and $E\left(y_{0} \mid w=0\right)=E\left(y_{0}\right)$. Self-selection into treatment in our case could e.g. occur if firms having a low leverage or a high ETR are especially attractive targets. Starting from low leverage an increase in leverage is more likely to occur. Equivalently starting from a high ETR a decrease is more likely to occur. Then the observed change is not actually due to treatment but instead due to specific firms selecting into treatment. It is thus crucial that we eliminate this possibility to interpret our results.

While due to self-selection mean independence typically does not hold $\left(E\left(y_{1} \mid w=1 \neq\right.\right.$ $E\left(y_{1}\right)$ and $\left(E\left(y_{0} \mid w=0\right) \neq E\left(y_{0}\right)\right)$, the core idea of matching is to assume mean independence conditional on a vector of covariates $\boldsymbol{x}: E\left(y_{1} \mid w=1, \boldsymbol{x}\right)=E\left(y_{0}\right)$ and $\left(E\left(y_{0} \mid w=0, \boldsymbol{x}\right)=E\left(y_{0}\right)\right.$. If selection into treatment is determined by the covariates $\boldsymbol{x}$, then controlling for these covariates allows for a meaningful comparison of outcomes between treated and non-treated firms. 
We follow Rosenbaum and Rubin (1983) and predict the likelihood of being a target using a probit regression (selection equation) for all firms in our sample. The predicted probability for being acquired (the propensity score) is then the basis for finding actual targets versus non-targets with statistically identical covariates $\boldsymbol{x}$. The balancing property shows whether this procedure is successful or not.

Table 2 presents the results of the selection equation and the variables appearing in the model are defined in the Appendix. We use a probit estimation where the dependent variable is one if a firm becomes a target and zero otherwise. Targets involved in international deals could systematically differ from targets involved in national deals. We thus consider international and national takeovers as separate treatments. The matching procedure then guarantees the comparability between targets and matches irrespective of their involvement in international or national takeovers. In the second column and third column of Table 2 we present the respective probit regression results. Similarly, we consider the takeovers of tax aggressive vs. non tax aggressive acquirers as separate treatments.

In the selection equation we use a profitability measure to proxy for a firm's management efficiency as proposed in Palepu (1986). Profitability is earnings before interest and taxes (EBIT) over total assets and has a positive effect on takeover probability. Further we follow Palepu (1986) in using the log of total assets as a measure for the size of the firm. We find an increase in the likelihood to become a target with size.

Following Dietrich and Sorensen (1984) we use the firm's leverage (total debt over total assets) and capital expenditures (change over three periods in fixed assets over total assets) as controls. While Dietrich and Sorensen find no significant effects for these controls, we find leverage to have a positive, and capital expenditures to have a negative, effect on takeover 
probability. We further find a firm's cash holdings as a share of total assets to have a negative effect.

High growth is a dummy for firms with an above sample mean increase over three periods in total assets and affects takeover positively. Research intensity is intangible assets over total assets and only affects the international takeover probability. Tangibility defined as fixed assets over total assets has a negative effect. In addition we use inventories as a share of total assets as an indicator for firms active in trade, and find a negative effect.

All target specific controls besides for high growth and capital expenditures enter as the average over the three years preceding the takeover and are marked by (avg.). Thus the value of the controls should not yet be influenced by the takeover. We control for the target's macroeconomic environment (see Erel, Liao, and Weisbach 2012) using stocks traded, log labor force, target country exports, log GDP, spending on education and the inflation rate. All macroeconomic controls are lagged. We additionally control for the effective tax rate (ETR), but we do not find a significant effect. In order to control for unobserved heterogeneity, we use country, industry and time specific effects.

- Insert Table 2 about here -

Table 3 shows the balancing property based on radius matching taking all deals as treatments. Through the matching we achieve a significant reduction in bias. Thus, we believe the matching procedure works fairly well in our case.

- Insert Table 3 about here - 


\section{Results}

4.1. Descriptive evidence. We start by providing some descriptive evidence on changes in indicators of a target's tax avoidance behavior following a takeover. Figure 3 shows the evolution of the mean target ETRs (defined as tax expense divided by pre-tax income) starting from five periods pre-deal to five periods post-deal. ${ }^{13}$ Zero is defined as the point of time where the deal is completed. Pre-deal the ETR fluctuates around 28 percent. Post-deal the level of the ETR decreases and fluctuates around 20 percent. This holds for both national (solid green line) and international (dashed red line) mergers and acquisitions. Figure 3 provides some evidence for a decreased ETR following mergers and acquisitions.

- Insert Figure 3 about here -

Figure 4 shows in the same manner the evolution of target profitability (defined as earnings before interest and taxes over total assets) starting from five periods pre-deal to five periods post-deal. There is some initial evidence for a drop following the acquisition at point of time zero. This holds for national as well as international mergers and acquisitions. Target profitability fluctuates around 9 percent pre-deal and 5 percent post-deal.

- Insert Figure 4 about here -

\footnotetext{
${ }^{13}$ For calculating the mean target ETR we consider all target observations available. The mean is thus based on fewer observations e.g. for the period five pre deal. We do not show the 3-year average here, since then e.g. the period -1 result would already be affected by the deal.
} 
Figure 5 shows the evolution of target leverage (defined as total debt over total assets). Target leverage decreases steadily from five periods pre-deal to five periods post-deal for international mergers and acquisitions. There is no clear trend for national takeovers.

- Insert Figure 5 about here -

All these figures provide suggestive evidence on the evolution of a target's ETR, profitability and leverage post-deal. However, it is not possible to conclude on mergers and acquisitions being causal for the observed evolution. It may well be the case that the observed evolution of a target's ETR, profitability and leverage post-deal would have occurred irrespective of the target being sold to a new owner. To interpret such a causal relationship we employ more sophisticated econometrics as described above in Section 3.2. Using propensity score matching, we separate the change post-deal of a target's ETR, profitability and leverage caused by mergers and acquisitions from the change that most likely would have occurred irrespective of the transaction.

4.2. Main results. Table 4 shows the average effect of treatment on a target's average ETR in the three years following the takeover based on propensity score matching. Comparing targets and similar non-targets, we find a decrease in the ETR. This result holds irrespective of the matching algorithm - radius or kernel - and irrespective of whether treatment is defined as all, only international or only national takeovers. The reduction is around 3 percentage points for all takeovers.

A target's tax avoidance increases post-deal. The resulting reduction in tax payments is able to generate an ownership advantage. The observed decrease of the ETR cannot be due to 
a step up of the target's assets, since we focus exclusively on corporations as targets. If at all with corporations as targets a step up should occur with respect to the shares at the level of the shareholder (see Erickson and Wang, 2000), which would not affect the ETR.

- Insert Table 4 about here -

Table 5 presents the average effect of treatment on a target's average ETR in the three years following the takeover, depending on the acquirer's tax aggressiveness. Tax aggressive acquirers are acquirers with a 3-year mean ETR above the acquirer country specific sample 3year mean ETR in the same time period. We find a larger decrease in a target's ETR following an acquisition by a tax aggressive acquirer. While the decrease is around 8 percentage points (radius matching) or even 10 percentage points (kernel matching) following an acquisition by a tax aggressive acquirer, it is insignificant following an acquisition by a non-tax aggressive acquirer in the case of radius matching and only around 4 percentage points in the case of kernel matching. Acquirers appear to use their tax planning expertise to restructure the target's affairs in a tax efficient manner.

- Insert Table 5 about here -

Table 6 presents the results with respect to the change in average target profitability in the three years following the takeover. Consistent with Ravenscraft and Scherer (1989) and Clark and Ofek (1994) we observe a decrease in target profitability. However, we do not find a 
systematic larger decrease following international takeovers as we would expect from a tax perspective.

- Insert Table 6 about here -

Thus, we further differentiate takeovers with respect to the relative tax rates of the target versus the acquirer in Table 7. Targets facing a higher statutory tax rate relative to their acquirer are high-tax targets, and they are low-tax targets otherwise. Only in the case of a high-tax target is shifting profits out of the target an advisable strategy for the acquirer. Consistent with this expectation, we observe a decrease in target profitability for high-tax targets, while we do not find any significant change for low-tax targets. Finally, acquirers do not appear to shift profits into low-tax targets. ${ }^{14}$

\section{- Insert Table 7 about here -}

Table 8 alternately uses information on the acquirer's group structure obtained from the Amadeus owner database to differentiate between high-tax targets and low-tax targets. Targets having a statutory tax rate above the minimum tax rate faced by any member of the acquirer's group are now defined as high-tax targets. They are low-tax targets otherwise. Again, we find a significant decrease in target profitability for high-tax targets only. For legal (e.g. because of controlled foreign corporation rules) as well as practical reasons (e.g.

\footnotetext{
${ }^{14}$ This result may also be due to noise in the data. We precisely identify the group of high tax targets. However, due to incomplete information on the acquirer's group structure we may erroneously classify targets as low tax. This makes the correct identification of tax planning more difficult in this case
} 
because of established business relationships between the acquirer and the target) it is easier to shift profits from the target to the acquirer directly instead of shifting profits to a low-tax group member of the acquirer. We thus observe a lower point estimate for the decrease in profitability in Table 8 compared to Table 7.

- Insert Table 8 about here -

Table 9 finally presents the results with respect to changes in the 3-year average leverage in the years following the takeover. While we find some evidence for an increase in leverage based for all deals, we do not find a systematically larger increase following international takeovers, as we would expect from a tax perspective. We neither find significant changes if we differentiate between high tax and low tax targets as in Table 7. Thus, Table 9 provides no evidence for a tax-motivated increase in target leverage.

- Insert Table 9 about here -

\subsection{Sensitivity analyses.}

4.3.1. Group taxation. It is difficult to load a target with additional debt post-deal. While it is in general possible to load such debt on a target's books, the critical issue is what to do with the excess liquidity generated in doing so. Raising debt to finance the deal would be a natural candidate. However, such debt cannot enter on the books of the target, since these financial means are employed to acquire the target itself. The only feasible possibility is to distribute the retained earnings of the target and replace them with debt. This may however 
cause taxes on the distributions. Further, pre-deal creditors of the target may oppose to such a strategy, since it worsens their position in the case of default. Our results finding no significant change in target leverage post deal indicate that this strategy is not employed on a large scale due to such costs of debt finance.

A more tax efficient and widely applied (see Ruf 2011) strategy is to acquire targets not directly, but instead via a holding set up in the same country as the target (debt push-down). Figure 6 illustrates such a strategy. ${ }^{15}$ As the advantage of this strategy it is possible to load the holding with debt in order to acquire the target. After the transaction the holding's interest expenses on the debt to acquire the target are consolidated with the target's earnings making use of group taxation regimes. The debt shown on the books of the holding acts as it were shown on the books of the target. This reduces the incentive to load the target with debt itself and could be an explanation for us not finding clear evidence for an increase in target leverage following mergers and acquisitions.

- Insert Figure 6 about here -

In order to test this possibility, we consider targets located in countries offering no group taxation separately. ${ }^{16}$ In such countries the debt push down strategy does not work. Since it is not possible to load an acquiring holding tax efficiently with debt in such countries, there should be a stronger incentive to load the target itself with debt.

\footnotetext{
${ }^{15}$ See also Delauriere (2011), Brincker (2008), and http://www.mondaq.com/x/539/Audit/Dutch+Debtpushdown+Structures for a discussion of the use of debt push-down structures.

${ }^{16}$ In our sample these are (101) targets located in Belgium (60), Bulgaria (5), Czech Republic (14), Estonia (5), Lithuania (4), Romania (10) and Slovakia (3).
} 
Indeed - when focusing on targets in countries with no group taxation regime only- we find evidence for target leverage to increase after the takeover as presented in Table 10. Target leverage increases by around 8 percentage points. Acquirers loading holdings instead of targets with debt in countries offering group taxation could thus be an explanation for us finding no effect on target leverage above. We are not able to split up the results in national and international mergers and acquisitions in Table 10, since the sample of targets in countries without group taxation regimes is too small to do so.

- Insert Table 10 about here -

4.3.2. Exact matching. As a robustness check we employ three exact matching procedures: for countries, for industries and for country-years. We thus only match targets and controls from the same country in the first case, from the same industry in the second case and from the same country and year in the third case. Table 11 shows the radius matching results. Results do not materially change compared to section 4.2. We still observe evidence for a decreased ETR following mergers and acquisitions. We find some evidence for a decrease in profitability and an increase in leverage. However, as before we neither find a systematic larger decrease in profitability nor a larger increase in leverage following international takeovers as we would expect from a tax perspective.

\section{Conclusions}

More tax avoidance within targets post-acquisition increases the cash flow available to acquirers, allowing acquirers to outbid initial owners. Tax avoidance is one possible driver of 
mergers and acquisitions. We investigate the change in the tax avoidance of targets postacquisition using a sample of European mergers and acquisitions taking place between 1996 and 2009.

We consider three aspects of tax avoidance: First, a target's effective tax rate (ETR) as a measure reflecting aggressive tax planning through permanent book-tax differences; second, target profitability as a proxy to measure tax induced profit shifting; third, target leverage as an indicator for tax induced debt shifting.

A target's ETR decreases by 3 percentage points post deal and even by 8 percentage points if the acquirer is particularly tax aggressive. Further target profitability decreases following mergers and acquisitions. This decrease is especially pronounced for targets having a higher statutory tax rate than the acquirer. Tax induced profit shifting is one explanation for the empirical finding of decreased target profitability.

We do not find evidence for changes in target leverage post deal in general. However, we find empirical evidence for group taxation being an explanation for this finding: Restricting our sample to targets from countries without group taxation regimes results in a significant increase in leverage post deal. In countries offering group taxation regimes acquirers may prefer to load the acquiring holding instead of the target itself with debt. This results in similar tax savings, but is easier to achieve. 


\section{References}

Auerbach, A. and D. Reishus (1987), The impact of taxation on mergers and acquisitions, Mergers and Acquisitions, Alan J. Auerbach, ed., University of Chicago Press.

Becker, J. and C. Fuest (2010). Taxing foreign profits with international mergers and acquisitions. International Economic Review 51 (1), 171-186.

Blouin, J. L., J. H. Collins, and D. A. Shackelford (2005). Does acquisition by non-U.S. shareholders cause U.S. firms to pay less tax? Journal of the American Taxation Association 27 (1), 25 - 38.

Brincker, Emil (2008). Debt push-down facilities smoothen BEE deals. Business Law \& Tax Review, July.

Chen, S., X. Chen, Q. Cheng, and T. Shevlin (2010). Are family firms more tax aggressive than non-family firms? Journal of Financial Economics 95 (1), 41 - 61.

Chow, T., K. Klassen, Y. Liu (2013). Shareholder wealth effects of tax aggressiveness transfer. University of Waterloo working paper.

Clark, K. and E. Ofek (1994). Mergers as a means of restructuring distressed firms: An empirical investigation. Journal of Financial \& Quantitative Analysis 29 (4), 541 - 565.

Col, B. (2012). Havenly acquisitions. McGill University working paper.

Creal, D., L. A. Robinson, J. Rogers, and S. L. Zechman (2013). The multinational advantage. Chicago Booth Paper No. 11-37.

Delauriere, Jerome (2011). U.S. debt push-down in a French subsidiary - The good and the bad. Tax Analysts, March 9, 2011.

Desai, M. A., C. F. Foley, and J. R. Hines (2004). A multinational perspective on capital structure choice and internal capital markets. Journal of Finance 59 (6), 2451 - 2487.

Desai, M. A. and J. R. Hines (2003). Evaluating international tax reform. National Tax Journal 56 (3), 487-502.

De Simone, L., and J. Seidman (2013). Unprofitable affiliates and income shifting behavior. Stanford University working paper.

Devos, E., P. R. Kadapakkam, and S. Krishnamurthy (2009). How do mergers create value? A comparison of taxes, market power, and efficiency improvements as explanations for synergies. Review of Financial Studies 22 (3), 1179 - 1211. 
Dietrich, J. K. and E. Sorensen (1984). An application of logit analysis to prediction of merger targets. Journal of Business Research 12 (3), 393 - 402.

Dyreng, S. D., M. Hanlon, and E. L. Maydew (2008). Long-run corporate tax avoidance. Accounting Review 83 (1), $61-82$.

Dyreng, S. D., M. Hanlon, and E. L. Maydew (2010). The effects of executives on corporate tax avoidance. Accounting Review 85 (4), 1163 - 1189.

Erickson, M. (1998). The effect of taxes of the structure of corporate acquisitions. Journal of Accounting Research 36 (2), 279 - 298.

Erickson, M., and S Wang. 2000. The effect of transaction structure on price: Evidence from subsidiary sales, Journal of Accounting and Economics 30, 59 - 97.

Erel, I., R. C. Liao, and M. S. Weisbach (2012). Determinants of cross-border mergers and acquisitions. Journal of Finance 67 (3), 1045 - 1082.

Hanlon, M. and S. Heitzman (2010). A review of tax research. Journal of Accounting \& Economics 50 (2/3), 127 - 178.

Hansen, R. G. (1987). A theory for the choice of exchange medium in mergers and acquisitions. Journal of Business 60 (1), 75 - 95.

Hines, Jr., J. R. and E. M. Rice (1994). Fiscal paradise: Foreign tax havens and American business. Quarterly Journal of Economics 109 (1), 149 - 182.

Huizinga, H. and L. Laeven (2008). International profit shifting within multinationals: A multi-country perspective. Journal of Public Economics 92 (5/6), 1164 - 1182.

Huizinga, H., L. Laeven, and G. Nicodeme (2008). Capital structure and international debt shifting. Journal of Financial Economics 88 (1), 80 - 118.

Huizinga, H. and J. Voget (2009). International taxation and the direction and volume of cross-border M\&As. Journal of Finance 64 (3), 1217 - 1249.

Kaplan, S. (1989). Management buyouts: Evidence on taxes as a source of value. Journal of Finance 44 (3), $611-632$.

Klassen, K. and S. LaPlante (2012). Are U.S. multinational corporations becoming more aggressive income shifters? Journal of Accounting Research 50 (5), 1245-1286.

Martin, X., C. Wang, and H. Zou (2012). Does target tax aggressiveness matter in corporate takeovers? SSRN Working Paper. 
Martynova, M. and L. Renneboog (2008). A century of corporate takeovers: What have we learned and where do we stand? Journal of Banking \& Finance 32 (10), 2148 - 2177.

Mills, L., M. M. Erickson, and E. Maydew (1998). Investments in tax planning. Journal of the American Taxation Association 20 (1), 1 - 20.

Palepu, K. G. (1986). Predicting takeover targets. Journal of Accounting \& Economics 8 (1), $3-35$.

Phillips, J. D. (2003). Corporate tax-planning effectiveness: The role of compensation-based incentives. The Accounting Review 78 (3), 847 - 874.

Ravenscraft, D. J. and F. Scherer (1989). The profitability of mergers. International Journal of Industrial Organization 7 (1), $101-116$.

Rego, S. O. (2003). Tax avoidance activities of U.S. multinational corporations. Contemporary Accounting Research 20 (4), 805 - 855.

Rosenbaum, P. R. and D. B. Rubin (1983). The central role of the propensity score in observational studies for causal effects. Biometrika 70 (1), $41-55$.

Ruf, M. (2011). Why is the response of multinationals' capital structure choice to tax incentives that low? Some possible explanations. Finanzarchiv 67 (2), 123 - 144.

Scholes, M. S., M. A. Wolfson, M. Erickson, E. L. Maydew, and T. Shevlin (2009). Taxes and Business Strategy A Planning Approach (4 ed.). Upper Saddle River, NJ: Pearson Prentice Hall.

UNCTAD (2012). World Investment Report 2012. Geneva: United Nations Conference on Trade and Development.

Weston, J. F., M. Mitchell, and J. H. Mulherin (2004). Takeovers, restructuring, and corporate governance (4 ed.). Upper Saddle River, NJ: Pearson Prentice Hall.

Wooldridge, J. M. (2002). Econometric analysis of cross section and panel data. Cambridge, Mass.: MIT Press. 
FIGURE 1. Illustration of debt shifting

Financial Statement pre acq.

Financial Statement post acq.

\begin{tabular}{l|l} 
Assets & Liabilities \\
\hline BA & Capital
\end{tabular}

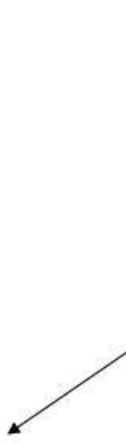

Debt claim where?

Taxes paid

Taxes paid

FIGURE 2. Regional origin of acquirers of European target firms

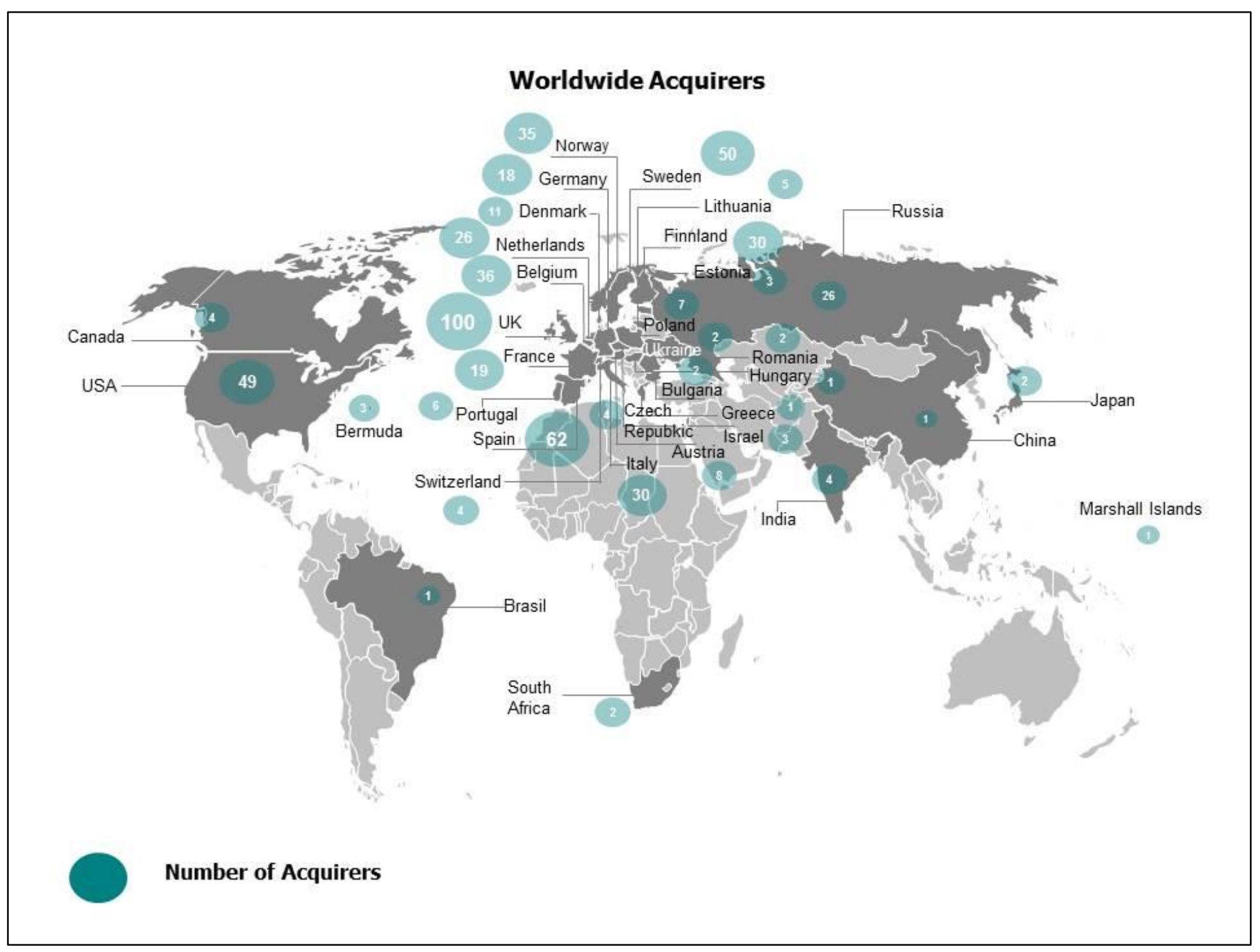


FIGURE 3. Target effective tax rate (ETR) pre and post deal

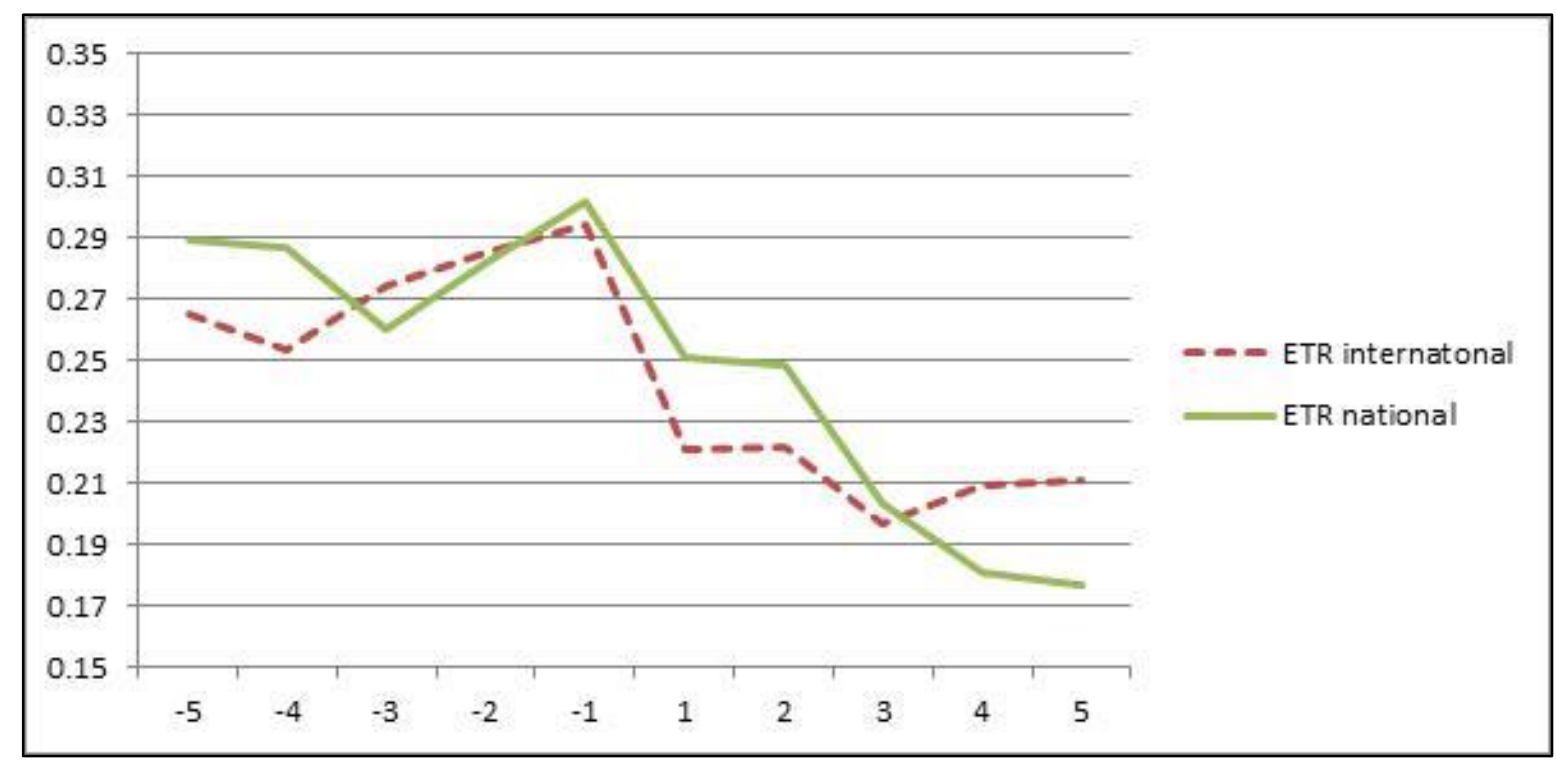

Note: The effective tax rate (ETR) is tax expense (Amadeus: TAXA) divided by pre-tax income (Amadeus: PLBT). The figure shows the mean ETR across all target observations available in a certain period. Period -5 is 5 years pre deal and period 5 is 5 years post deal. In an international deal, the acquirer and target are resident in a different country. In a national deal, the acquirer and target are resident in the same country. Source: Bureau van Dijk Amadeus database.

FIGURE 4. Target profitability pre and post deal

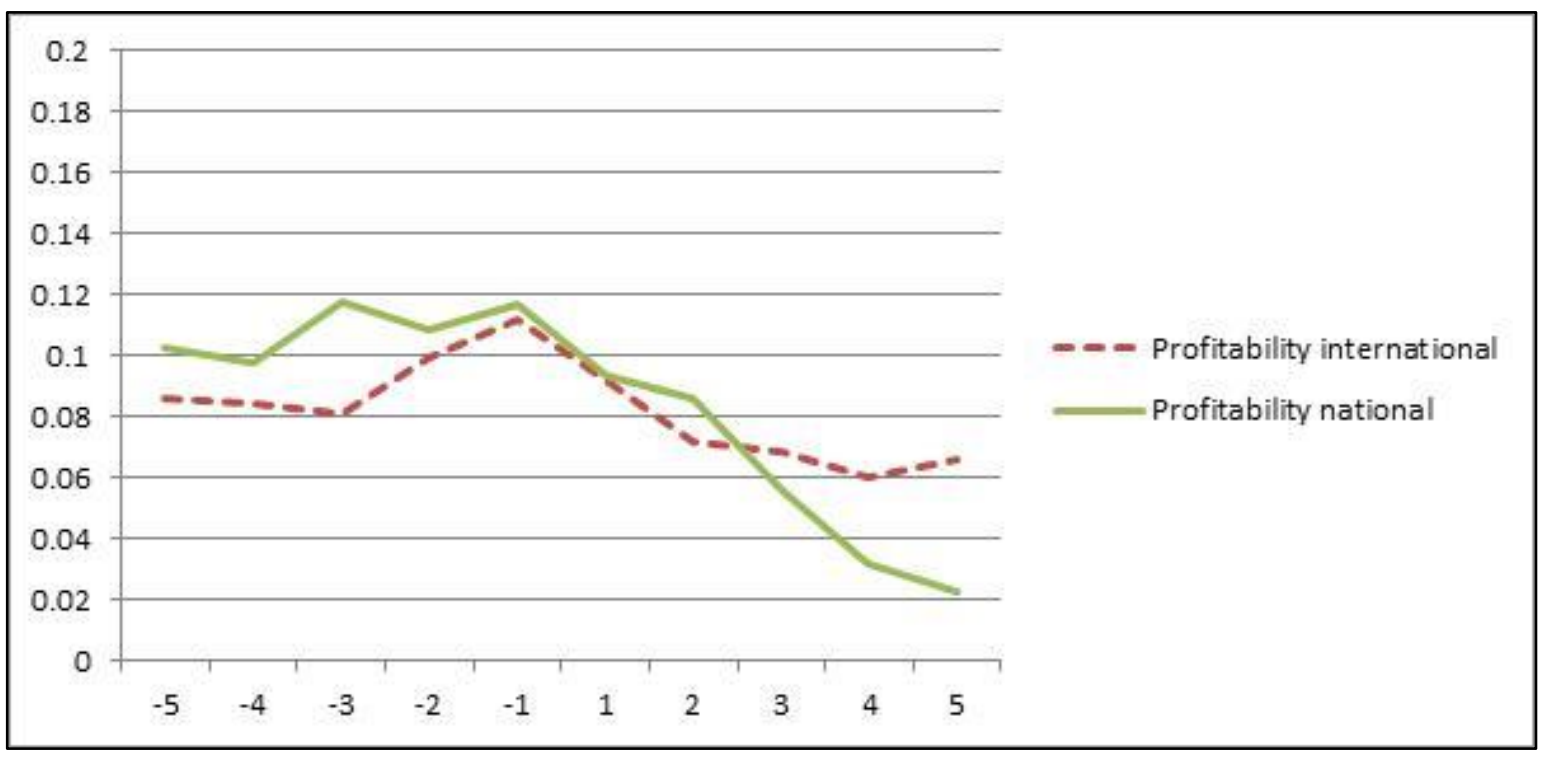

Note: Profitability is earnings before interest and taxes divided by total assets. The figure shows the mean profitability across all target observations available in a certain period. Period -5 is 5 years pre deal, and period 5 is 5 years post deal. In an international deal, the acquirer and target are resident in a different country. In a national deal, the acquirer and target are resident in the same country. Source: Bureau van Dijk Amadeus database. 
FIGURE 5. Target leverage pre and post deal

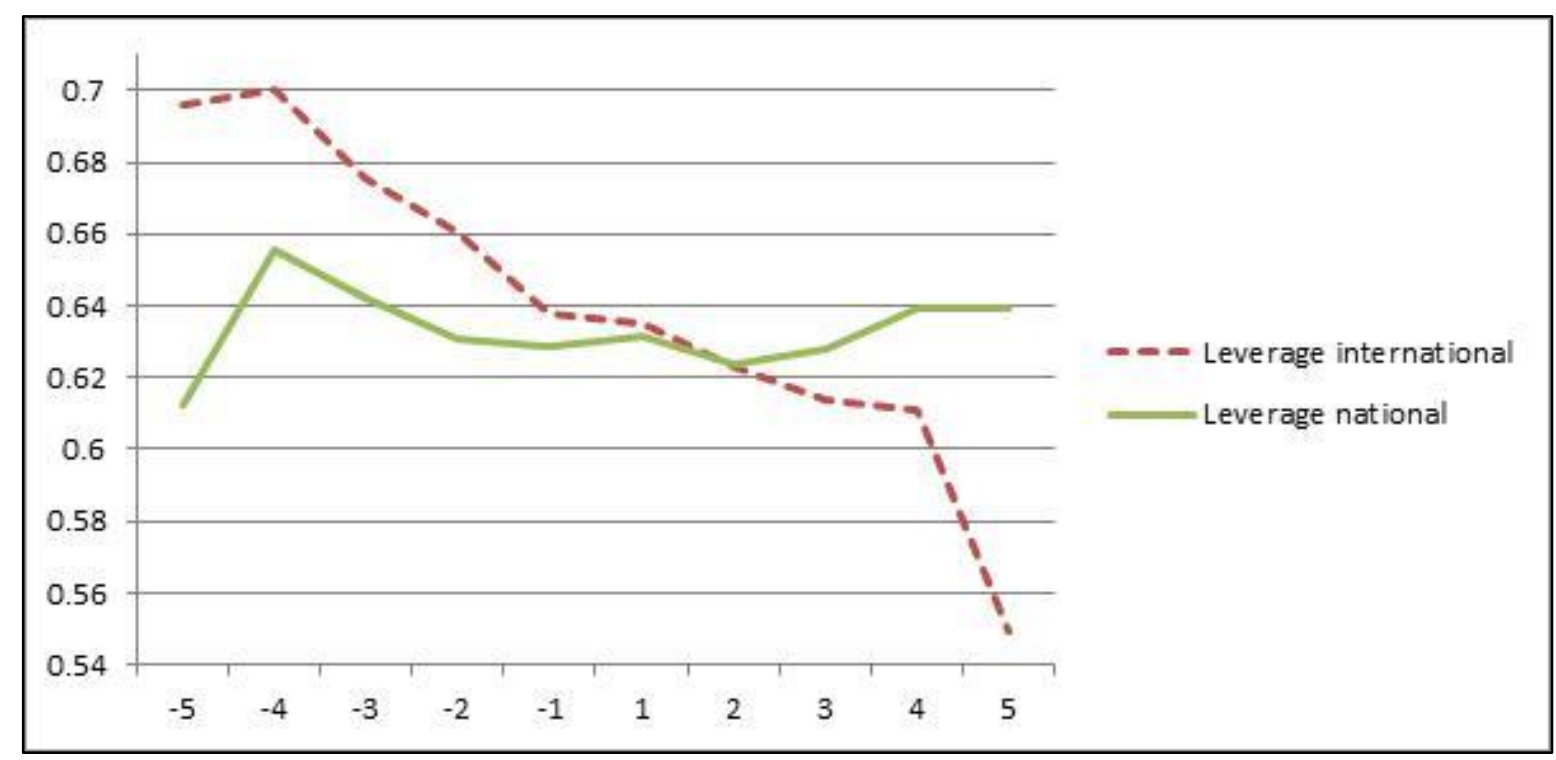

Note: Leverage is total liabilities divided by total assets. The figure shows the mean leverage across all target observations available in a certain period. Period -5 is 5 years pre deal and period 5 is 5 years post deal. In an international deal, the acquirer and target are resident in a different country. In a national deal, the acquirer and target are resident in the same country. Source: Bureau van Dijk Amadeus database. 
FIGURE 6. Illustration of debt push-down strategy in group taxation regime

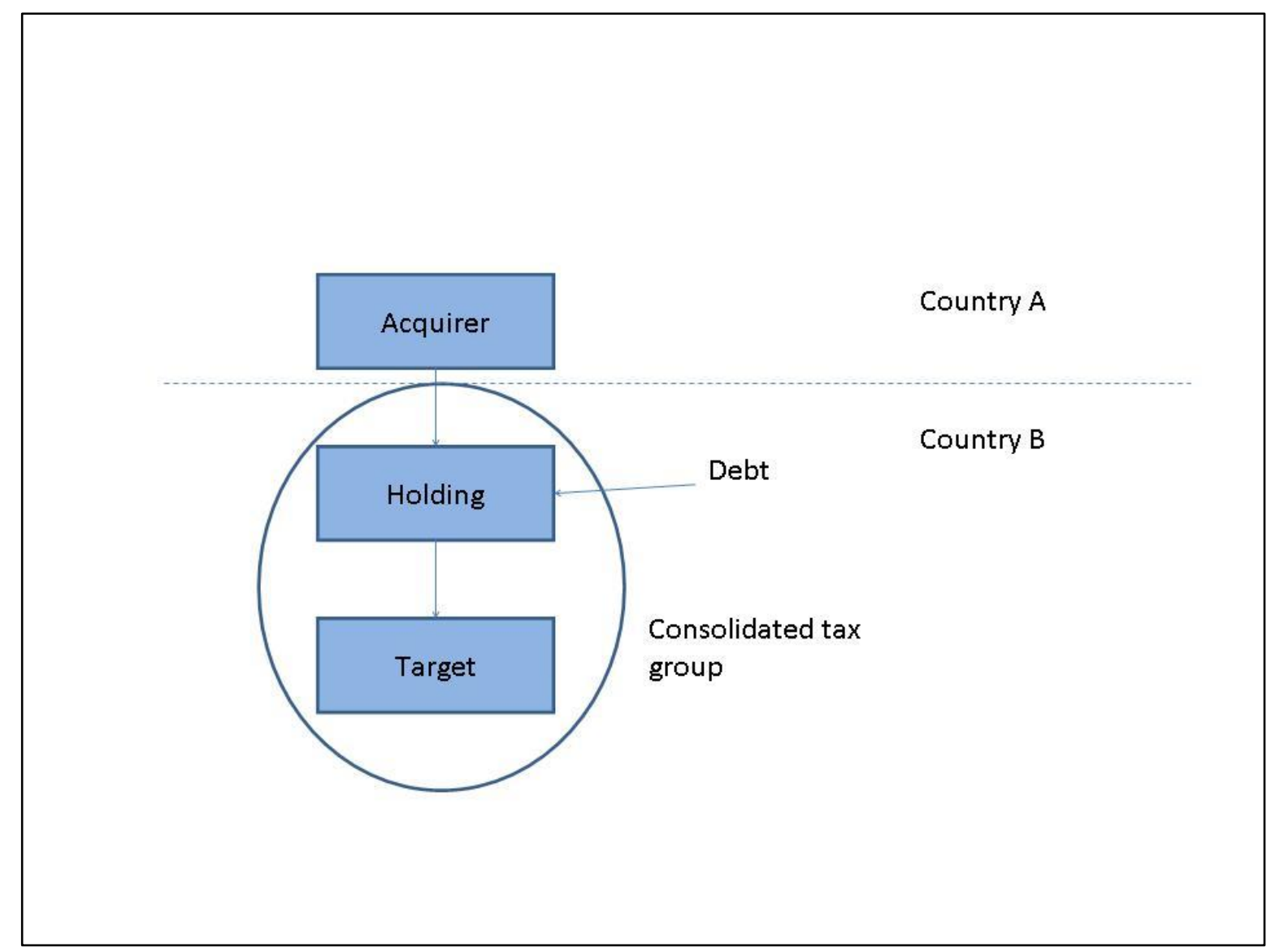

Note: Country B offers a group taxation regime whereby the taxable income (loss) of the holding company may be combined with the taxable income (loss) of the target firm in computing taxable income in County B for the group (consisting of the holding company and the target firm). In practice, a debt push-down strategy enables interest deductions generated in the holding to offset operating income generated in the target. 
TABLE 1. Descriptive statistics

\begin{tabular}{lrrrrr}
\hline Variable & Observations & Mean & $\begin{array}{c}\text { Standard } \\
\text { Deviation }\end{array}$ & Minimum & Maximum \\
& & & & \\
\hline ETR (av) & 1970957 & 0.338 & 0.217 & 0.000 & 1.000 \\
Profitability (av) & 1970957 & 0.102 & 0.123 & -0.367 & 0.620 \\
Leverage (av) & 1970957 & 0.683 & 0.255 & 0.051 & 1.692 \\
Cash (av) & 1970957 & 0.121 & 0.141 & 0.000 & 0.698 \\
High Growth & 1970957 & 0.072 & 0.259 & 0.000 & 1.000 \\
Log (Total Assets) (av) & 1970957 & 14.389 & 1.763 & 8.685 & 19.038 \\
Research Intensity (av) & 1970957 & 0.024 & 0.061 & 0.000 & 0.462 \\
Tangibility (av) & 1970957 & 0.299 & 0.243 & 0.000 & 0.951 \\
Inventories (av) & 1970957 & 0.207 & 0.216 & 0.000 & 0.939 \\
Capital Expenditures & 1970957 & 0.064 & 0.174 & -0.519 & 0.752 \\
Stocks Traded & 1970957 & 81.741 & 64.947 & 0.035 & 367.043 \\
Log (Labor Force) & 1970957 & 16.652 & 0.964 & 12.019 & 18.121 \\
Exports & 1970957 & 35.682 & 14.300 & 24.414 & 99.145 \\
Log (GDP) & 1970957 & 10.017 & 0.508 & 8.471 & 10.896 \\
Spending on Education & 1970957 & 4.732 & 0.964 & 2.400 & 7.635 \\
Inflation Rate & 1970957 & 0.044 & 0.045 & -0.011 & 0.456 \\
\hline
\end{tabular}

Note: For the definition and the sources of the variables see the Appendix. 
TABLE 2. Selection equation

\begin{tabular}{|c|c|c|c|}
\hline Independent variable & All & International & National \\
\hline \multirow{2}{*}{ ETR (av) } & -0.104 & -0.103 & -0.080 \\
\hline & $(-1.43)$ & $(-1.07)$ & $(-0.81)$ \\
\hline \multirow[t]{2}{*}{ Profitability (av) } & $0.504 * * *$ & $0.581 * * *$ & $0.342 * *$ \\
\hline & $(4.86)$ & $(4.24)$ & $(2.52)$ \\
\hline \multirow[t]{2}{*}{ Leverage (av) } & $0.078 *$ & $0.129 *$ & 0.013 \\
\hline & $(1.73)$ & $(2.16)$ & $(0.22)$ \\
\hline \multirow[t]{2}{*}{ Cash (av) } & $-0.162 * *$ & $-0.132 * *$ & -0.185 \\
\hline & $(-1.96)$ & $(-1.28)$ & $(-1.53)$ \\
\hline \multirow[t]{2}{*}{ High Growth } & $0.100 * *$ & $0.060 * *$ & $0.147 * *$ \\
\hline & $(2.26)$ & $(1.07)$ & $(2.34)$ \\
\hline \multirow[t]{2}{*}{ Log (Total Assets) (av) } & $0.146 * * *$ & $0.161 * * *$ & $0.110 * * *$ \\
\hline & $(22.92)$ & $(19.97)$ & $(12.22)$ \\
\hline \multirow[t]{2}{*}{ Research Intensity (av) } & 0.216 & 0.469 & -0.164 \\
\hline & $(1.54)$ & $(2.89)$ & $(-0.71)$ \\
\hline \multirow[t]{2}{*}{ Tangibility (av) } & $-0.220 * * *$ & $-0.335 * * *$ & -0.065 \\
\hline & $(-4.37)$ & $(-5.25)$ & $(-0.92)$ \\
\hline \multirow[t]{2}{*}{ Inventories (av) } & $-0.307 * * *$ & $-0.363 * * *$ & $-0.206^{* *}$ \\
\hline & $(-4.72)$ & $(-4.30)$ & $(-2.30)$ \\
\hline \multirow[t]{2}{*}{ Capital Expenditures } & $-0.294 * * *$ & $-0.198 * * *$ & $-0.363 * * *$ \\
\hline & $(-4.69)$ & $(-2.53)$ & $(-4.04)$ \\
\hline \multirow[t]{2}{*}{ Stocks Traded } & $0.001 * * *$ & $0.001 * * *$ & $0.001 * * *$ \\
\hline & $(2.60)$ & $(1.38)$ & $(2.50)$ \\
\hline \multirow[t]{2}{*}{ Log (Labor Force) } & $2.390 * * *$ & $2.678 * * *$ & $1.945^{*}$ \\
\hline & $(3.23)$ & $(2.79)$ & $(1.85)$ \\
\hline \multirow[t]{2}{*}{ Exports } & $0.021 * *$ & $0.017 * *$ & $0.028 * * *$ \\
\hline & $(2.24)$ & $(1.29)$ & $(2.41)$ \\
\hline \multirow[t]{2}{*}{$\log (\mathrm{GDP})$} & $1.147 * * *$ & $0.506 * * *$ & $1.725 * * *$ \\
\hline & $(3.36)$ & $(1.08)$ & $(3.73)$ \\
\hline \multirow[t]{2}{*}{ Spending on Education } & 0.036 & 0.002 & 0.053 \\
\hline & $(0.55)$ & $(0.03)$ & $(0.52)$ \\
\hline \multirow[t]{2}{*}{ Inflation Rate } & $-2.889 * * *$ & $-3.796 * * *$ & -1.249 \\
\hline & $(-3.12)$ & $(-3.16)$ & $(-0.86)$ \\
\hline Country Dummy & Yes & Yes & Yes \\
\hline Year Dummy & Yes & Yes & Yes \\
\hline Industry Dummy & Yes & Yes & Yes \\
\hline Number of Obs. & $1,970,957$ & $1,896,418$ & $1,944,545$ \\
\hline Pseudo- $\mathrm{R}^{2}$ & 0.1316 & 0.1410 & 0.1082 \\
\hline
\end{tabular}

Note: Results from probit regressions. The dependent variable is one if a firm becomes a target and zero otherwise in the column labeled 'All'. The dependent variable is one if a firm becomes a target due to an international takeover and zero otherwise in the column labeled 'International. The dependent variable is one if a firm becomes a target due to a national takeover and zero otherwise in the column labeled 'National'. For the definition and the sources of the variables see the Appendix. T-statistics based on robust standard errors in parentheses. The symbols $* * *, * *$, and $*$ denote significance at the $0.01,0.05$, and 0.10 levels, respectively. 
TABLE 3. Balancing property - All

\begin{tabular}{|c|c|c|c|c|c|c|}
\hline \multirow[b]{2}{*}{ Variable } & \multicolumn{2}{|c|}{ Mean } & \multirow[b]{2}{*}{ Bias in $\%$} & \multirow{2}{*}{$\begin{array}{l}\text { Bias } \\
\text { Reduction } \\
\text { in } \%\end{array}$} & \multicolumn{2}{|r|}{ t-test } \\
\hline & Treated & Control & & & t-stat & p-value \\
\hline ETR (av) & 0.284 & 0.282 & 0.7 & 97.8 & 0.13 & 0.897 \\
\hline Profitability (av) & 0.102 & 0.112 & -7.5 & -346.6 & -1.23 & 0.219 \\
\hline Leverage (av) & 0.646 & 0.639 & 2.6 & 83.6 & 0.44 & 0.662 \\
\hline Cash (av) & 0.114 & 0.126 & -8.3 & -245.3 & -1.30 & 0.192 \\
\hline High Growth & 0.164 & 0.166 & -0.5 & 97.7 & -0.07 & 0.942 \\
\hline Log (Total Assets) (av) & 15.952 & 15.757 & 11.8 & 88.4 & 1.95 & $0.052 *$ \\
\hline Research Intensity (av) & 0.029 & 0.026 & 4.0 & 49.7 & 0.61 & 0.545 \\
\hline Tangibility (av) & 0.349 & 0.335 & 5.8 & 70.0 & 0.91 & 0.362 \\
\hline Inventories (av) & 0.152 & 0.152 & -0.2 & 99.4 & -0.03 & 0.975 \\
\hline Capital Expenditures & 0.043 & 0.050 & -3.7 & 73.6 & -0.58 & 0.562 \\
\hline Stocks Traded & 80.994 & 82.195 & -2.2 & 91.8 & -0.34 & 0.736 \\
\hline Log (Labor Force) & 16.182 & 16.173 & 0.9 & 97.9 & 0.13 & 0.894 \\
\hline Exports & 39.140 & 39.642 & -3.2 & 87.4 & -0.48 & 0.632 \\
\hline $\log (\mathrm{GDP})$ & 10.108 & 10.114 & -1.2 & 96.3 & -0.23 & 0.818 \\
\hline Spending on Education & 5.414 & 5.440 & -2.3 & 96.1 & -0.36 & 0.722 \\
\hline Inflation Rate & 0.027 & 0.026 & 0.6 & 98.8 & 0.13 & 0.900 \\
\hline
\end{tabular}

Note: For the definition and the sources of the variables see the Appendix.

TABLE 4. Average effective tax rate

\begin{tabular}{|c|c|c|c|c|c|c|}
\hline Matching algorithm & All & & International & & National & \\
\hline Radius & $\begin{array}{l}-0.030 \\
(-4.34)\end{array}$ & & $\begin{array}{l}-0.036 \\
(-3.98)\end{array}$ & $* * *$ & $\begin{array}{l}-0.022 \\
(-1.96)\end{array}$ & $* *$ \\
\hline Kernel & $\begin{array}{c}-0.037 \\
(-5.28)\end{array}$ & $* * *$ & $\begin{array}{c}-0.049 \\
(-5.44)\end{array}$ & $* * *$ & $\begin{array}{c}-0.041 \\
(-3.63)\end{array}$ & $* * *$ \\
\hline $\begin{array}{l}\text { Number of Treated } \\
\text { Number of Untreated }\end{array}$ & $\begin{array}{c}529 \\
1,180,076\end{array}$ & & $\begin{array}{c}308 \\
1,142,988\end{array}$ & & $\begin{array}{c}221 \\
1,167,070\end{array}$ & \\
\hline
\end{tabular}

Note: We report coefficients that correspond to the average treatment effect on the treated (ATT); T-statistics in parentheses. The outcome variable average effective tax rate (ETR) is defined as a firm's average ETR in the three years following the takeover. The 'All' column reports the coefficient based on the selection equation in Table 2 that considers all takeovers as treatments, the 'International' column reports the coefficient based on the selection equation in Table 2 that considers only international takeovers as treatments, and the 'National' column reports the coefficient based on the selection equation in Table 2 that considers only national takeovers as treatments. The symbols $* * *, * *$, and $*$ denote significance at the $0.01,0.05$, and 0.10 levels, respectively. 
TABLE 5. Average effective tax rate - tax vs. non tax aggressive acquirer

\begin{tabular}{lcc}
\hline Matching algorithm & Tax aggressive acquirer & Non tax aggressive acquirer \\
\hline Radius & $-0.075 * * *$ & -0.012 \\
& $(-3.10)$ & $(-0.59)$ \\
Kernel & $-0.104 * * *$ & $-0.040 *$ \\
& $(-4.28)$ & $(-1.84)$ \\
Number of Treated & 50 & 57 \\
Number of Untreated & $1,097,309$ & $1,113,250$ \\
\hline
\end{tabular}

Note: We report coefficients that correspond to the average treatment effect on the treated (ATT); T-statistics in parentheses. The outcome variable average effective tax rate (ETR) is defined as a firm's average ETR in the three years following the takeover. The column tax aggressive acquirer gives the coefficient considering only takeovers by tax aggressive acquirers as treatments, the column non-tax aggressive acquirers gives the coefficient considering only takeovers by non-tax aggressive acquirers as treatments. Tax aggressive acquirers are acquirers with a three-year mean ETR above the acquirer country specific sample three-year mean ETR in the same time period. The symbols $* * *, * *$, and * denote significance at the $0.01,0.05$, and 0.10 levels, respectively.

TABLE 6. Average profitability

\begin{tabular}{lccc}
\hline Matching algorithm & All & International & National \\
\hline Radius & $-0.015 * * *$ & $-0.015^{* *}$ & $-0.017 * *$ \\
Kernel & $(-2.76)$ & $(-1.96)$ & $(-2.09)$ \\
& $-0.014 * *$ & -0.012 & $-0.014 *$ \\
& $(-2.54)$ & $(-1.63)$ & $(-1.72)$ \\
Number of Treated & & & \\
Number of Untreated & 529 & 308 & 221 \\
\hline
\end{tabular}

Note: We report coefficients that correspond to the average treatment effect on the treated (ATT); T-statistics in parentheses. The outcome variable average profitability is defined as a firm's average EBIT over total assets in the three years following the takeover. The 'All' column results are based on the selection equation in Table 2 that considers all takeovers as treatments, the 'International' column results are based on the selection equation in Table 2 that considers only international takeovers as treatments, and the 'National' column results are based on the selection equation in Table 2 that considers only national takeovers as treatments. The symbols ***, **, and $*$ denote significance at the $0.01,0.05$, and 0.10 levels, respectively. 
TABLE 7. High tax and low tax targets

\begin{tabular}{|c|c|c|}
\hline Matching algorithm & High tax targets & Low tax targets \\
\hline & \multicolumn{2}{|c|}{ Average profitability } \\
\hline Radius & $\begin{array}{c}-0.046 * * * \\
(-3.41)\end{array}$ & $\begin{array}{l}-0.004 \\
(-0.48)\end{array}$ \\
\hline Kernel & $\begin{array}{c}-0.043 * * * \\
(-3.19)\end{array}$ & $\begin{array}{l}-0.002 \\
(-0.22)\end{array}$ \\
\hline Number of Treated & 81 & 227 \\
\hline Number of Untreated & $1,142,988$ & $1,142,988$ \\
\hline & \multicolumn{2}{|c|}{ Average leverage } \\
\hline Radius & $\begin{array}{l}0.020 \\
(0.86)\end{array}$ & $\begin{array}{l}0.019 \\
(1.22)\end{array}$ \\
\hline Kernel & $\begin{array}{l}0.006 \\
(0.26)\end{array}$ & $\begin{array}{l}0.010 \\
(0.63)\end{array}$ \\
\hline Number of Treated & 81 & 227 \\
\hline Number of Untreated & $1,142,988$ & $1,142,988$ \\
\hline
\end{tabular}

Note: We report coefficients that correspond to the average treatment effect on the treated (ATT); T-statistics in parentheses. The outcome variable average profitability is defined as a firm's average earnings before interest and taxes (EBIT) over total assets in the three years following the takeover. The outcome variable average leverage is defined as a firm's average total liabilities over total assets in the three years following the takeover. The column high tax gives the results for high tax targets, the column low tax the results for low tax targets. Targets having a statutory rate above the acquirer's tax rate are defined as high tax targets. They are low tax targets otherwise. Results are based on the selection equation in Table 2 that considers all takeovers as treatments. The symbols ***, $* *$, and $*$ denote significance at the $0.01,0.05$, and 0.10 levels, respectively. 
TABLE 8. High tax and low tax targets - minimum statutory tax rate of the group

\begin{tabular}{|c|c|c|}
\hline Matching algorithm & High tax & Low tax \\
\hline & \multicolumn{2}{|c|}{ Average profitability } \\
\hline Radius & $\begin{array}{l}-0.025 * * * \\
(-2.61)\end{array}$ & $\begin{array}{l}-0.005 \\
(-0.41)\end{array}$ \\
\hline Kernel & $\begin{array}{c}-0.021 * * \\
(-2.28)\end{array}$ & $\begin{array}{l}-0.003 \\
(-0.25)\end{array}$ \\
\hline $\begin{array}{l}\text { Number of Treated } \\
\text { Number of Untreated }\end{array}$ & $\begin{array}{c}160 \\
1,142,988\end{array}$ & $\begin{array}{c}148 \\
1,142,988\end{array}$ \\
\hline & \multicolumn{2}{|c|}{ Average leverage } \\
\hline Radius & $\begin{array}{l}0.008 \\
(0.48)\end{array}$ & $\begin{array}{l}0.032 \\
(1.55)\end{array}$ \\
\hline Kernel & $\begin{array}{l}-0.004 \\
(-0.29)\end{array}$ & $\begin{array}{l}0.024 \\
(1.15)\end{array}$ \\
\hline Number of Treated & 160 & 148 \\
\hline Number of Untreated & $1,142,988$ & $1,142,988$ \\
\hline
\end{tabular}

Note: We report coefficients that correspond to the average treatment effect on the treated (ATT); T-statistics in parentheses. The outcome variable average profitability is defined as a firm's average EBIT over total assets in the three years following the takeover. The outcome variable average leverage is defined as a firm's average total liabilities over total assets in the three years following the takeover. The column high tax gives the results for high tax targets, the column low tax the results for low tax targets. Targets having a statutory tax rate above the acquirer's group minimum tax rate are defined as high tax targets. They are low tax targets otherwise. Results are based on the selection equation in Table 2 that considers all takeovers as treatments. The symbols $* * *, * *$, and * denote significance at the $0.01,0.05$, and 0.10 levels, respectively. 
TABLE 9. Average leverage

\begin{tabular}{lccc}
\hline Matching algorithm & All & International & National \\
\hline Radius & $0.031 * * *$ & 0.020 & $0.047 * * *$ \\
& $(2.97)$ & $(1.49)$ & $(2.81)$ \\
Kernel & $0.026 * *$ & 0.009 & 0.025 \\
& $(2.44)$ & $(0.68)$ & $(1.50)$ \\
Number of Treated & & & \\
Number of Untreated & 529 & 308 & 221 \\
\hline
\end{tabular}

Note: We report coefficients that correspond to the average treatment effect on the treated (ATT); T-statistics in parentheses. The outcome variable average leverage is defined as a firm's average total liabilities over total assets in the three years following the takeover. The 'All' column reports the coefficient based on the selection equation in Table 2 that considers all takeovers as treatments, the 'International' column reports the coefficient based on the selection equation in Table 2 that considers only international takeovers as treatments, and the 'National' column reports the coefficient based on the selection equation in Table 2 that considers only national takeovers as treatments. The symbols $* * *, * *$, and * denote significance at the $0.01,0.05$, and 0.10 levels, respectively.

TABLE 10. Average leverage - countries without group taxation regime only

\begin{tabular}{lc}
\hline Radius & $0.081 * * *$ \\
Kernel & $(3.28)$ \\
& $0.076 * * *$ \\
Number of Treated & $(3.08)$ \\
Number of Untreated & 101 \\
\hline
\end{tabular}

Note: We report coefficients that correspond to the average treatment effect on the treated (ATT); T-statistics in parentheses. The outcome variable average leverage is defined as a firm's average total liabilities over total assets in the three years following the takeover. Results are based on the selection equation in Table 2 that considers all takeovers as treatments and on a sample including only countries without a group taxation regime. In our sample these are Belgium, Bulgaria, Czech Republic, Estonia, Lithuania, Romania and Slovakia. The symbols $* * *, * *$, and $*$ denote significance at the $0.01,0.05$, and 0.10 levels, respectively. 
TABLE 11. Exact matching

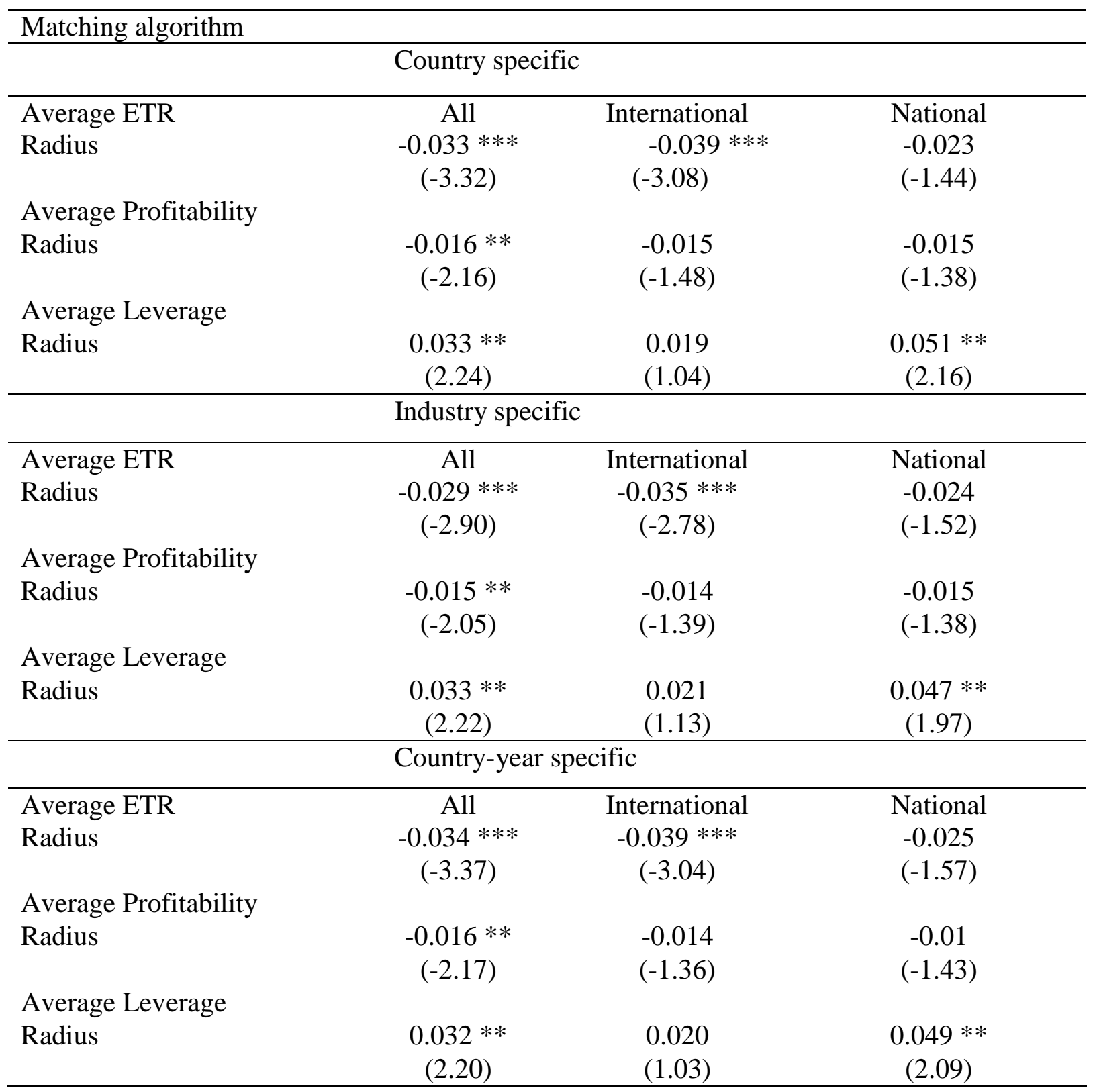

Note: We report coefficients that correspond to the average treatment effect on the treated (ATT); T-statistics in parentheses. Results are propensity score matching results after exact matching according to country, industry or country-year. The outcome variable average ETR is defined as a firm's average ETR in the three years following the takeover. The outcome variable average profitability is defined as a firm's average EBIT over total assets in the three years following the takeover. The outcome variable average leverage is defined as a firm's average total liabilities over total assets in the three years following the takeover. The 'All' column results are based on the selection equation in Table 2 that considers all takeovers as treatments, the 'International' column results are based on the selection equation in Table 2 that considers only international takeovers as treatments, and the 'National' column results are based on the selection equation in Table 2 that considers only national takeovers as treatments. The symbols $* * *, * *$, and $*$ denote significance at the $0.01,0.05$, and 0.10 levels, respectively. 


\section{APPENDIX}

TABLE 12. Variable definitions

\begin{tabular}{|c|c|}
\hline Variable name & Definition \\
\hline ETR (av) & $\begin{array}{l}\text { A firm's tax expense (TAXA) divided by pre-tax income } \\
\text { (PLBT) (3-year average). The ETR is winsorized into the }(0,1) \\
\text { interval. Source: Bureau van Dijk Amadeus Database. }\end{array}$ \\
\hline Profitability (av) & $\begin{array}{l}\text { A firm's Earnings before interest and tax (EBIT)/Total assets (3- } \\
\text { year average); Source: Bureau Van Dijk Amadeus Database. }\end{array}$ \\
\hline Leverage (av) & $\begin{array}{l}\text { A firm's Total liabilities/Total assets (3-year average). Source: } \\
\text { Bureau van Dijk Amadeus Database. }\end{array}$ \\
\hline Cash (av) & $\begin{array}{l}\text { A firm's (Cash }+ \text { Cash equivalents)/Total assets (3-year } \\
\text { average). Source: Bureau van Dijk Amadeus Database. }\end{array}$ \\
\hline High Growth & $\begin{array}{l}\text { Dummy variable that takes on the value } 1 \text { for a firm whose } \\
\text { annual growth rate of "Total assets" is above the average growth } \\
\text { rate and } 0 \text { otherwise. }\end{array}$ \\
\hline Log (Total Assets) (av) & $\begin{array}{l}\text { Natural logarithm of a firm's Total assets (3-year average). } \\
\text { Source: Bureau van Dijk Amadeus Database. }\end{array}$ \\
\hline Research intensity (av) & $\begin{array}{l}\text { A firm's Intangible assets/Total assets (3-year average). Source: } \\
\text { Bureau van Dijk Amadeus Database. }\end{array}$ \\
\hline Tangibility (av) & $\begin{array}{l}\text { A firm's Fixed assets/ Total assets (3-year average). Source: } \\
\text { Bureau van Dijk Amadeus Database. }\end{array}$ \\
\hline Inventories (av) & $\begin{array}{l}\text { A firm's Inventory/Total assets (3-year average). Source: Bureau } \\
\text { van Dijk Amadeus Database. }\end{array}$ \\
\hline Capital Expenditures & $\begin{array}{l}\text { Difference in a firm's fixed assets between one year and three } \\
\text { years preceding the acquisition / Total assets. Source: Bureau } \\
\text { van Dijk Amadeus Database. }\end{array}$ \\
\hline Stocks Traded & $\begin{array}{l}\text { Ratio of stock market capitalization to GDP of the target } \\
\text { country. Source: World Development Indicators, Worldbank } \\
\text { Database. }\end{array}$ \\
\hline
\end{tabular}




\begin{tabular}{|c|c|}
\hline Variable name & Definition \\
\hline Log (Labor Force) & $\begin{array}{l}\text { Total labor force comprises people aged } 15 \text { and older who meet } \\
\text { the International Labour Organization definition of the } \\
\text { economically active population (logarithm). Source: World } \\
\text { Development Indicators, Worldbank Database. }\end{array}$ \\
\hline Exports & $\begin{array}{l}\text { Ratio of Exports of goods and services to GDP of the target } \\
\text { country. Source: World Development Indicators, Worldbank } \\
\text { Database. }\end{array}$ \\
\hline $\log (\mathrm{GDP})$ & $\begin{array}{l}\text { The natural logarithm of the target's country purchase price } \\
\text { parity (ppp) converted GDP per capita. Source: Penn World } \\
\text { Tables. }\end{array}$ \\
\hline Spending on Education & $\begin{array}{l}\text { Ratio of Public expenditure on education to GDP of the target } \\
\text { country. Source: World Development Indicators, Worldbank } \\
\text { Database. }\end{array}$ \\
\hline Inflation Rate & $\begin{array}{l}\text { Inflation as measured by the consumer price index of the target } \\
\text { country. Source: World Development Indicators, Worldbank } \\
\text { Database. }\end{array}$ \\
\hline
\end{tabular}

Note: All averages (avg.) are calculated for the three years preceding the acquisition. All macroeconomic variables refer to the year preceding the acquisition. All financial data is winsorized at the $1 \%$ level. 